\title{
Impact of Microfinance on Rural Households in the Philippines
}

\author{
Toshio Kondo, Aniceto Orbeta, Jr, Clarence Dingcong and \\ Christine Infantado*
}

\begin{abstract}
1 Introduction
This article reports on the impact evaluation study of the Rural Microenterprise Finance Project (RMFP) in the Philippines. RMFP aimed to support efforts of the Government of the Philippines to strengthen rural financial institutions by assisting organisations that employed the Grameen Bank Approach (GB) in providing credit to the poor. The objective of the project was to reduce poverty, create employment opportunities, and enhance the incomes of the poorest of the rural poor (the ultra poor) - the bottom 30 per cent of the rural population - as measured by income. Rural banks, cooperative rural banks, cooperatives, thrift banks and nongovernmental organisations (NGOs) participated in the nationwide implementation of the project, which ended in December 2002.
\end{abstract}

\section{Framework, survey design and data, and estimation procedure \\ 2.1 Framework for assessing impact on households The key problem in evaluation is finding a valid counterfactual against which the treatment group is compared. The gold standard in impact evaluation is a randomised experiment where treatment and control groups are randomly determined. Since this study was conducted ex post, i.e. evaluating an}

already completed project, it could not employ a randomised experiment.

\begin{abstract}
Moreover, the study also did not have the benefit of baseline data. Hence, the evaluation uses a one-time survey, employing a quasi-experimental pipeline design as used by Coleman (1999) in his study of microfinance in Thailand. The design is summarised in Table 1. Each 'treatment' barangay (village) is matched to a different 'comparison' barangay. ${ }^{1}$ The importance of having a different barangay rather than say a new centre in the same barangay has been explained in Coleman (1999). The treatment barangays are those where the Grameen Bank Approach Replicators (GBAR) programme, particularly lending, have been going on for some time. The comparison barangays, on the other hand, are expansion areas where programme clients have been identified and organised into groups but no loans have yet been released to them. In both the treatment and comparison barangays an equivalent number of qualified but non-participating households were also interviewed.
\end{abstract}

The innovation introduced in the study, not used by Coleman, is the inclusion in the group of client households, former clients consisting of graduates, and problem households. This was designed to

Table 1 Evaluation strategy: type of household respondent

\begin{tabular}{lll}
\hline Type of households $(\mathrm{HH}) /$ area & 'Treatment' (existing) area & 'Comparison' (expansion) area \\
\hline Participating HH & (A1) Existing clients & (C) New clients \\
& (A2) Former clients (graduates; & \\
problem clients) &
\end{tabular}

IDS Bulletin Volume 39 Number 1 March 2008 (c) Institute of Development Studies 
Table 2 Evaluation strategy: factors determining outcomes

\begin{tabular}{lll}
\hline Type of households $(\mathbf{H H})$ /area & 'Treatment' (existing) area & 'Comparison' (expansion) area \\
\hline Participating HH & (A) & (C) \\
& - Observable characteristics & - Observable characteristics \\
& - Unobservable characteristics & - Unobservable characteristics \\
& affecting participation & affecting participation \\
& - Area attributes (T) & - Area attributes (C) \\
& - Microfinance programme & \\
(B) & (D) \\
- Observable characteristics & - Observable characteristics \\
& - Area attributes (T) & - Area attributes (C)
\end{tabular}

address the attrition/dropout problem in using new clients as a comparison group, i.e., the new client group included would-be graduates and future problem clients (Karlan 2001).

From Table 1, impact is given by the expression:

$$
\text { (1) Impact }=(A-B)-(C-D)
$$

This is also known in the literature as the differencein-difference (DID) method. To see how the DID method generates a clean measure of impact, the cells in Table 1 can be filled by the factors that determine outcomes for each of the different household clients. This is shown in Table 2.2

The new clients will not have the impact of the microfinance programme because, even if they have already been identified as prospective clients, they have not yet received loans. Non-participating households will neither have the effect of unobservable characteristics affecting participation nor the impact of the microfinance programme because they have not participated in the programme. A process of elimination will explain why the DID method described earlier will give the desired estimate of the impact of the microfinance programme. The expression ( $A-B)$ will give the net effects of unobserved characteristics affecting participation plus the microfinance impact. Incidentally, this also highlights the effect of not controlling for sample selection bias. The expression (C-D), on the other hand, will give the net effect of the unobserved characteristics affecting participation.
Thus, (A-B)-(C-D) will yield the net effect of the microfinance programme. It is noteworthy that if we don't enumerate non-participating households and compare existing and new clients, $(\mathrm{A}-\mathrm{C})$ will give us the effect of the microfinance programme plus the difference between the treatment area and comparison area effects which need not be identical, particularly if programme placement is not random. Finally, if the treatment group does not include the appropriate number of former clients (graduates and problem) the impact of both the observable characteristics and the unobservable characteristics will be different for the existing and new clients as well. This is called the attrition/dropout bias.

The DID strategy described above is implemented in a regression framework. The advantage of using the regression framework is that it can account for the differences in household and community characteristics which can happen even with a well-designed sampling scheme in a quasi-experimental design. Specifically, the following equation was estimated:

$$
\text { (2) } Y_{i j}=F\left(\beta_{1} X_{i j}+\beta_{2} V_{j}+\beta_{3} M_{i j}+\beta_{4} T_{i j}+\varepsilon_{i j}\right)
$$

where:

$$
\begin{aligned}
& Y_{i j}=\text { household outcome of interest } \\
& X_{i j}=\text { household characteristics } \\
& V_{i}=\text { village characteristics } \\
& M_{i j}=\text { membership dummy; } 1 \text { if participant in } \\
& \text { existing and expansion areas; } 0 \text { otherwise } \\
& T_{i j}=\text { treatment variable; } 1 \text { (or }>0 \text { ) if participant in } \\
& \text { treatment area }^{3}
\end{aligned}
$$


The F() function can be linear or non-linear depending on the nature of the dependent variable of interest. This expression is identical to the formulation in Coleman (1999), and Montgomery (2005) had employed a nearly identical evaluation strategy. As argued in Coleman (1999) and Armendariz de Aghion and Morduch (2005), conditional on the other regressors, the coefficient of $T_{i j}\left(B_{4}\right)$ measures the impact of microfinance operations on household outcomes $Y_{i j}$. Wooldridge (2002) provides a discussion of the assumptions required for this result to extend to specific nonlinear cases such as binary and corner solution responses.

This specification covers the three known sources of bias in evaluating the impact of microfinance services using new members as a comparison group. Control for non-random programme participation or sample selection is provided by using a membership dummy M (Coleman 1999). The literature (e.g. Coleman 1999, and Armendariz de Aghion and Morduch 2005) has amply shown that not controlling for sample selection results in biased estimates of the impact of microfinance services. Non-random programme placement, on the other hand, is controlled by village characteristics $V_{j}$ or fixed effects estimation (Khandker 1998). Finally, dropout bias is controlled for by including in the treatment group an appropriate number of randomly selected households who had dropped out of the programme (both for reasons of graduation and problems with repayments) as recommended in Karlan (2001).

\subsection{The survey}

The survey requires two types of areas. First, treatment areas or existing areas are defined as areas where the programme, particularly lending, has been ongoing for some time. In particular, existing clients considered for the survey are those who have been with the programme for at least three years or have availed themselves of loans for at least five loan cycles. This is designed to capture the impact of the subject project, i.e. the RMFP, the implementation of which was completed in 2002. Second, a corresponding set of expansion areas is defined as areas where prospective programme clients have been identified and organised into groups but no loans have yet been released to them. A suitable expansion area should be one that is different from an existing area. In particular, a new centre in a treatment area does not qualify as an expansion area.
The sampling design utilised the implementation structure of the RMFP. Participating microfinance institutions (MFIs) submit regular reports to the executing agency (EA) - the People's Credit and Finance Corporation (PCFC). The records of the PCFC provide the number of clients actually served by each MFI at the barangay level. There was no comprehensive record on expansion areas. While most of the participating MFls claimed to have expansion areas, a check with a few of the MFls, however, revealed that some did not have the suitable expansion areas needed by the study. The sampling then used the list of existing barangays as the sampling frame.

The sampling scheme considered the three island groups (Luzon, Visayas, Mindanao) and the type of MFI (cooperative banks/rural banks, cooperatives, and NGOs) as stratification variables. Based on existing programme records, it was determined that the most practical primary sampling unit (PSU) is the barangay. It was also determined, based on the estimates of the mean and variance of incomes from the Family Income and Expenditures Survey (FIES) in 2003, that a sample size of 2,200 households was sufficient for the study. For each barangay a sample of 10 client and 10 non-participating households was deemed sufficient. At this sampling rate per barangay, about 110 barangays or 55 treatment (existing) barangays, and 55 corresponding comparison (expansion) barangays will be required to generate the needed sample size.

The number of barangays for each island and for each MFI type is selected randomly proportional to the number of client households served - or sampling proportional to size (PPS). For every treatment barangay selected, the MFI concerned is asked to identify a corresponding suitable expansion area. The selection of a particular treatment barangay for inclusion in the survey is contingent on the MFI being able to identify a corresponding suitable expansion barangay. When the MFI cannot identify a suitable expansion barangay, the treatment barangay is replaced with a new draw from the pool of treatment barangays for the same MFI type. This process is repeated until the required number of treatment-expansion barangay pairs are generated for each of the MFI types. The existing and new client households are drawn randomly from the list prepared by the MFI or from the centres' roster of members. The non-participating households are 
Table 3 Sampling allocation by island group and type of MFI

\begin{tabular}{lrrr}
\hline Island group & Total no. of borrowers & \% & Treatment barangays \\
\hline & & & $\mathbf{5 5}$ \\
Grand total & $\mathbf{1 , 6 4 8 , 0 5 2}$ & 100 & $\mathbf{2 8}$ \\
Luzon & $\mathbf{7 9 7 , 1 9 4}$ & $\mathbf{4 8}$ & 18 \\
Banks & 485,984 & 61 & 2 \\
Coops & 70,461 & 9 & 8 \\
NGOs & 240,749 & 30 & $\mathbf{1 3}$ \\
Visayas & $\mathbf{4 1 9 , 1 2 3}$ & $\mathbf{2 5}$ & 2 \\
Banks & 67,125 & 16 & 2 \\
Coops & 69,046 & 16 & 9 \\
NGOs & 282,952 & 68 & $\mathbf{1 4}$ \\
Mindanao & $\mathbf{4 3 1 , 7 3 5}$ & $\mathbf{2 6}$ & 10 \\
Banks & 331,097 & 77 & 2 \\
Coops & 41,331 & 10 & 2 \\
NGOs & 59,307 & 14 & $\mathbf{5 5}$ \\
Total & $\mathbf{1 6 4 8 , 0 5 2}$ & 100 & 30 \\
Banks & 884,206 & 54 & 6 \\
Coops & 180,838 & 11 & 19 \\
NGO & 583,008 & 35 & \\
Source PCFC. & & & \\
\hline
\end{tabular}

drawn randomly from the list of qualified nonparticipating households identified by MFI field personnel, centre or barangay leaders. ${ }^{4}$

The total number of borrowers by island group and MFI type as of 30 June 2006 is given in Table 3. The corresponding allocation of the treatment barangays by island group and by MFI type is also given in the table. The survey covered 2,276 households in 116 barangays and $28 \mathrm{MFIs}$.

Three survey instruments were used in the study. One is the household survey questionnaire. The questionnaire is adopted from the Annual Poverty Indicators Survey (APIS) questionnaire conducted by the National Statistics Office. Added to the APIS questions are the detailed questions on loan accounts, enterprises, and gender-related matters. Another instrument is the Barangay Profile Questionnaire. Finally, there is the MFI Profile questionnaire. These instruments were pre-tested prior to the actual field surveys.

\subsection{Estimation procedure}

The estimation methodology considers the nature of the dependent variable and the treatment variable. It follows closely the estimation procedures described in Wooldridge (2002) for estimating the average treatment effects. Before discussing the estimation procedures, it is useful to discuss the nature of the treatment variables and the outcome variables considered in the study.

Outcome variables: Several outcome variables are considered in the study, namely: (a) basic household welfare measures such as per capita income, per capita expenditures, per capita savings, and food expenditures; (b) other financial transactions such as other (non-GBA) loans and personal savings stocks; ${ }^{5}$ (c) household enterprises and employment; (d) household assets such as land, farm equipment, livestock and poultry, and household appliances; and (e) human capital investments such as education and health. Some of these variables are continuous such as per capita income, expenditure, savings, food expenditure, health expenditure per capita, and education expenditure per attending child. Others are binary such as having a savings account and taking up a non-GBA loan. Others are truncated such as the value of household assets and other loans. Others are count variables such as the number of non-GBA loans, number of enterprises, and the 
number employed in those enterprises. Finally, others are proportions such as the proportion of school-age children attending school or proportion of those who are sick and sought treatment. Each of these different types of dependent variable requires different estimation methodology.

Treatment variables: There are four possible treatment variables that can be used to assess the impact of microfinance on household welfare. These are: (1) take-up of programme loan (1=yes, $\mathrm{O}=$ otherwise); (2) number of months the programme is available to the barangay (based on first loan released for the barangay); (3) value of loans (cumulative total amount of loans) taken up; and (4) number of loan cycles. The length of exposure to the programme is expected to have an impact. Therefore treatment variables (2)-(4) are deemed better in representing programme availability (Coleman 1999). It should be realised, however, that these treatment variables have different implications for estimation. For instance, perhaps only the first two satisfy the ignorability of treatment condition for treatment variables. ${ }^{6}$ Treatment variables (3) and (4) would fail the ignorability condition and would thus require instrumental variable estimation (Wooldridge 2002).

Other independent variables: The other independent variables used in the control functions are similar to those used in existing literature (e.g. Coleman 1999; Montgomery 2005). These include household characteristics such as age of the reference person (a.k.a. household head) or respondent; education of the reference person; number of years in the barangay, and house size. Age is expected to be a factor because it is well known that the age-earning profile is not flat. Education, of course, is a known determinant of both earning capacity and productivity in non-market (home) production. The number of years in the barangay is a proxy for social capital. House size is a proxy for household wealth. ${ }^{8}$ This is used because, among the household assets in the data, this is presumed to be the least volatile. For education and health equations, the variables indicating availability of relevant facilities are also added as explanatory variables.

Estimation method: The general estimation methodology can be labelled as a control function approach. This approach uses other independent variables as elements of some control function in addition to the treatment variable. The functional form of the control function depends on whether the outcome of interest can be modelled linearly or not. For outcomes that can be modelled linearly (i.e. $y=x \beta$ ) such as continuous variables, the elements of the control function include the other independent variables, such as household characteristics, and the interaction of the treatment variable and the demeaned values of the other independent variables. For linear models, the coefficient of the treatment variable provides the estimate of the DID average treatment effect. For outcomes that require nonlinear models (i.e. $y=F(x \beta))$ such as probit for binary outcomes, tobit for truncated outcomes or poisson for count outcomes, Wooldridge (2002) recommends that a propensity score method is more appropriate. Under this method the propensity score, which is the predicted value of the regression of the treatment variable on the other independent variables, and the product of the treatment variable and the demeaned values of the estimated propensity score are the elements in the control function. In non-linear models, the DID average treatment effect is given by the marginal effects of the treatment variable measured at the average values of the independent variables subject, of course, to satisfying the required assumptions. Note that the correction for sample selection is taken care of by the inclusion of a membership dummy among the explanatory variables. To take care of nonrandom programme placement, fixed effects estimation is used. ${ }^{9}$ However, in general, fixed effects estimation will result in inconsistent estimates when a non-linear model is estimated (Wooldridge 2002). Thus, for these models, random effects estimation was used. Admittedly, random effects estimation is more restrictive than fixed effects because it imposes a structure on the village effects. This is, however, considered better than the inconsistent estimates from fixed effects estimation with non-linear models. Finally, as mentioned earlier, the nature of the treatment variable also determines the estimation procedure. When the ignorability of treatment cannot be assumed (such as those for treatment variables (3) and (4)) instrumental variables (4) estimation is used (Wooldridge 2002). For lack of better instruments, we will use treatment variable $(2)^{10}$ as the instrument for all estimations using (3) and (4). The validity of the treatment variable (2) as an instrument emanates from the fact that whatever loans existing clients are able to get, as well the number of loan cycles, are both dependent on the 
Table 4 Characteristics of existing clients

\begin{tabular}{lc}
\hline Characteristics & Values \\
\hline Months since first loan & 75.2 \\
Total amount of loans, thousands & 69.923 \\
No. of loan cycles & 7.2 \\
Existing, \% & 89.1 \\
Graduate, \% & 2.1 \\
Problem, \% & 8.8 \\
Source Operations Evaluation Mission. &
\end{tabular}

number of months the programme is available in the area. In addition, this variable is determined by the $\mathrm{MFI}$ and is not within the control of the households.

\section{Estimation results}

\subsection{Respondent characteristics and outreach}

When RMFP was completed on 31 December 2002 618,906 clients were reached, of whom 97 per cent were women. When the survey design was being formulated in June 2006, records of the PCFC showed that the programme had served some 1.6 million borrowers. The survey showed that existing clients are, on average, on their 75th month in the programme (about 6 years and 3 months) (Table 4). They have each, on average, cumulatively taken up some PhP (Philippine pesos) 70,000 (US\$1,600) in loans and they are on their 7th loan cycle. It is also revealed that, on average, 9 per cent of existing clients are problem clients while 2 per cent are graduates.

Table 5 shows the demographic characteristics of all respondent households. It shows that the respondents are 44 years old on average. 15 per cent of the reference persons ${ }^{11}$ are female. In terms of education, below 1 per cent have no education, 31 per cent have some elementary education, 46 per cent have some secondary education and 23 per cent have tertiary education. The respondents have lived in the barangay for about 19 years on average and the average size of the house is 63 square metres. About 92 per cent of the respondents are female. Since, for existing clients, the respondents are the programme clients, one can say that programme clients are 95 per cent female. Table 6 shows the basic household welfare indicators. Using the official poverty threshold in 2006,12 the table also shows that only 10 per cent of the respondents are poor while 4 per cent are subsistence poor. ${ }^{13}$ This is quite revealing considering that the programme was designed to reach poor households.
Given the intention of the programme to serve poor households, the natural question to ask is, "is the programme reaching its intended target?'. To answer this question the distribution of the difference between the respondents' per capita income and the official poverty threshold was plotted. As such, a value of zero would mean the household is on the poverty line, a negative value would mean the household is below the poverty line and a positive value would mean the household is above the poverty line. Figures 1-3 show the histograms of the deviation of per capita income from the poverty threshold for existing clients, new clients, and non-participating households. The histograms reveal that while a large proportion of the respondents are around the poverty threshold more are on the non-poor side.

If one considers only existing clients, the histogram shows that while a considerable proportion of the existing clients are around the poverty threshold, a larger proportion is on the non-poor side (Figure 1). One can argue that perhaps when they entered the programme they were poorer than they are at the time of the survey. If one, however, looks at the profile of the new clients, one sees essentially the same distribution, i.e., larger proportions are on the non-poor side (Figure 2). Finally, the non-

participating households, which are households that people in the community consider to be qualified for the programme, also exhibit the same characteristics, i.e. most of them are not poor (Figure 3). These graphs reveal some very important pieces of information about the programme. One, since existing and new programme clients are supposed to have been screened using means-testing procedures, these procedures, assuming they have been applied strictly, are not correctly identifying the poor clients per official definition. Two, since non-participating households are households referred to by either programme field personnel, centre leaders, or barangay leaders as those who would qualify for the programme, these stakeholders in the field are also pointing out possible clients that are not the intended clients of the programme. This means that, in spite of the means-testing instruments used to identify the intended clients, all relevant stakeholders of the programme in the field are not pointing to the intended clients - the poor - as the qualified clients of the programme. This may indicate that perhaps the stakeholders are suggesting that those considered as officially poor may not be the desired clients of microfinance programmes. 
Table 5 Demographic characteristics of respondent

\begin{tabular}{|c|c|c|c|c|c|c|c|}
\hline \multirow[t]{2}{*}{ Variables } & \multicolumn{3}{|c|}{ Existing Areas } & \multicolumn{3}{|c|}{ Expansion Areas } & \multirow[t]{2}{*}{ Total } \\
\hline & $\begin{array}{l}\text { Partici- } \\
\text { pating }\end{array}$ & $\begin{array}{l}\text { Non- } \\
\text { partici- } \\
\text { pating }\end{array}$ & Sig. & $\begin{array}{l}\text { Partici- } \\
\text { pating }\end{array}$ & $\begin{array}{l}\text { Non- } \\
\text { partici- } \\
\text { pating }\end{array}$ & Sig. & \\
\hline $\begin{array}{l}\text { Age of reference } \\
\text { person (rp) }\end{array}$ & 47 & 43 & $* * *$ & 43 & 44 & & 44 \\
\hline Female, rp & 0.146 & 0.140 & & 0.127 & 0.197 & $* * *$ & 0.153 \\
\hline Less than elem, rp & 0.008 & 0.009 & & 0.009 & 0.004 & & 0.007 \\
\hline Elementary, rp & 0.337 & 0.273 & $*$ & 0.293 & 0.347 & & 0.312 \\
\hline Secondary, rp & 0.442 & 0.452 & & 0.484 & 0.442 & & 0.455 \\
\hline Tertiary, rp & 0.214 & 0.266 & $*$ & 0.214 & 0.207 & & 0.225 \\
\hline Years in barangay & 21.2 & 17.6 & $* * *$ & 17.6 & 18.0 & & 19 \\
\hline House size, sq.m. & 75.7 & 65.9 & $*$ & 59.4 & 51.2 & $* * *$ & 63 \\
\hline Female, respondent & 0.953 & 0.926 & & 0.905 & 0.911 & & 0.923 \\
\hline
\end{tabular}

3.2 Estimation results - impact of microfinance Impact on per capita income, expenditure, savings, and expenditure on food

The primary measures of household welfare are, of course, per capita income, expenditure, and food, as well as savings. These variables are continuous, hence, the estimation procedures use linear fixedeffects model. The control function variables include other independent variables, such as household characteristics, and the interaction of the treatment variable with the other independent variables (expressed as mean deviations). As mentioned in Section 3.3, four treatment variables can be used in the study, namely: (1) took up programme loan (1=yes, $\mathrm{O}=$ otherwise); (2) number of months the programme is available to the barangay (based on first loan

\begin{tabular}{|c|c|c|c|c|c|c|c|}
\hline \multirow[t]{2}{*}{ Variables } & \multicolumn{3}{|c|}{ Existing Areas } & \multicolumn{3}{|c|}{ Expansion Areas } & \multirow[t]{2}{*}{ Total } \\
\hline & $\begin{array}{l}\text { Partici- } \\
\text { pating }\end{array}$ & $\begin{array}{l}\text { Non- } \\
\text { partici- } \\
\text { pating }\end{array}$ & Sig. & $\begin{array}{l}\text { Partici- } \\
\text { pating }\end{array}$ & $\begin{array}{l}\text { Non- } \\
\text { partici- } \\
\text { pating }\end{array}$ & Sig. & \\
\hline Per capita income & 51,000 & 45,365 & $*$ & 43,737 & 43,456 & & 45,759 \\
\hline Per capita expenditure & 36,153 & 34,357 & & 30,674 & 31,898 & & 33,195 \\
\hline Per capita savings 1 & 14,847 & 11,007 & $* *$ & 13,064 & 11,558 & & 12,564 \\
\hline Per capita savings 2 & 18,425 & 14,508 & $* *$ & 15,454 & 14,210 & & 15,580 \\
\hline Per capita food exp. & 13,708 & 13,115 & & 12,540 & 13,145 & & 13,113 \\
\hline Poor la & 0.60 & 0.110 & $* * *$ & 0.093 & 0.120 & & 0.097 \\
\hline Subsistence poor lb & 0.025 & 0.042 & & 0.032 & 0.054 & & 0.039 \\
\hline
\end{tabular}

***, ${ }^{* *},{ }^{*}$ significant at $1 \%, 5 \%$ and $10 \%$ respectively; two-tailed hypothesis

Per capita savings 2 recognises that the benefits of expenditure on education, health and durable furniture extends beyond the current reference period. 
Figure 1 Distribution of sample existing client households around the poverty line

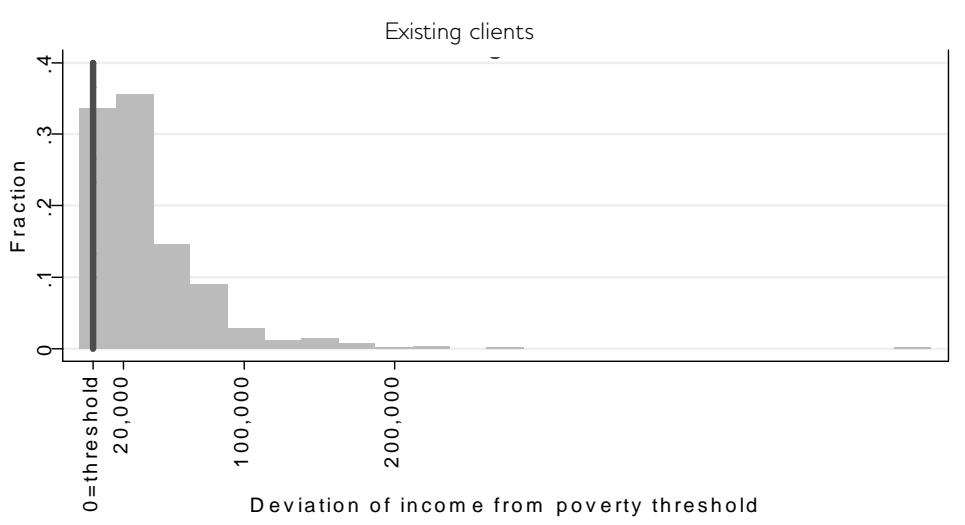

Source Operations Evaluation Mission.

Figure 2 Distribution of sample new client households around the poverty line

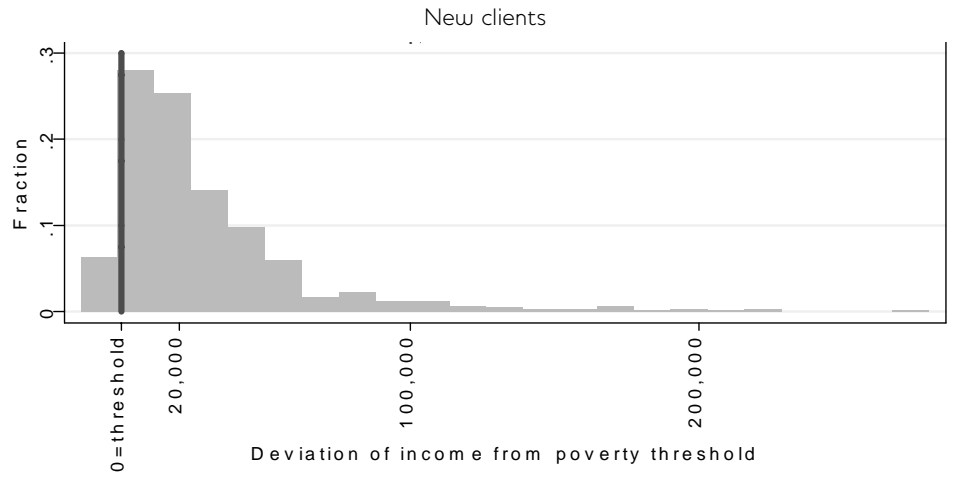

Source Operations Evaluation Mission.

Figure 3 Distribution of sample qualified non-participating households around the poverty line

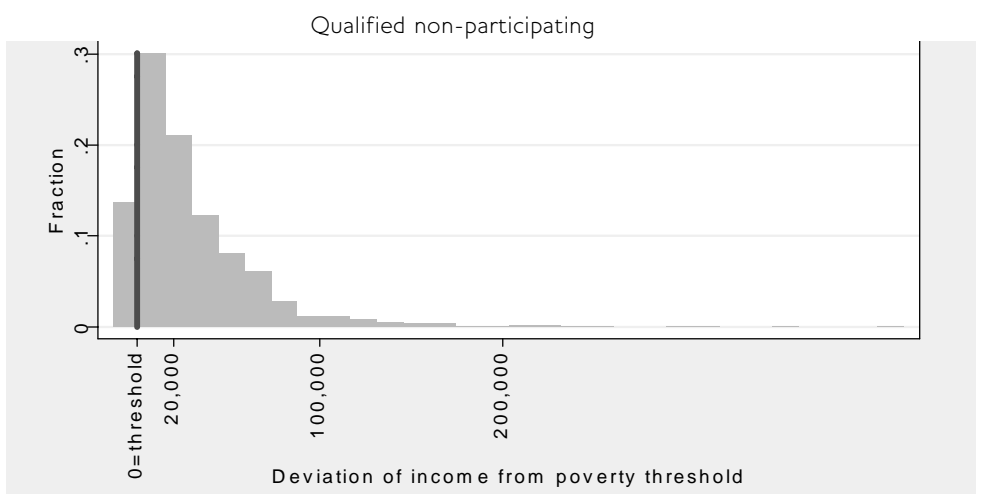

Source Operations Evaluation Mission.

8 Kondo et al. Impact of Microfinance on Rural Households in the Philippines 
Table 7 Impact on per capita income, expenditures, savings, food

\begin{tabular}{|c|c|c|}
\hline Outcome variables & $\begin{array}{l}\text { Estimated } \\
\text { coefficient }\end{array}$ & Sig. level \\
\hline Per capita income & 5,2 & 0.099 \\
\hline Per capita expenditures & 4,136 & 0.077 \\
\hline Per capita savings 1 la & & \\
\hline Per capita savings $2 \mathrm{lb}$ & & \\
\hline Per capita food exp. & 1,333 & 0.072 \\
\hline \multicolumn{3}{|c|}{$\begin{array}{l}a=\text { Income-Expenditure } \\
b=\text { Income-Expenditure }+ \text { Educ. }+ \text { Health+Dur. Funiture }\end{array}$} \\
\hline \multicolumn{3}{|c|}{ Source Operations Evaluation Mission. } \\
\hline
\end{tabular}

released for the barangay); (3) value of loans (cumulative total amount of loans) taken up and (4) number of loan cycles. Estimation results show that among the four, only the take-up of programme loan treatment variable proved to be significant and this is only true for per capita income, per capita consumption, and per capita food consumption, and not for the two savings definitions. The F-test on whether the fixed-effects coefficients are all equal to zero is rejected, which lends support to the hypothesis of non-random programme placement.

Table 7 shows the summary of the impact of take-up of programme loans on per capita income and per capita expenditures, on two definitions of per capita savings and per capita food expenditures. The table shows a slightly statistically significant (significance level 10 per cent) positive impact on per capita income of the take-up of programme loan treatment variable. The other treatment variables did not show significance even at the 10 per cent level. The estimated parameter says take-up of programme loan means higher income by about PhP5,222 (US\$120) compared to those who have not taken up loans. Translating this into impact per loan taken requires some calculation. The dependent variable is the average annual per capita income. Considering that on average households have taken up a cumulative PhP70,000 (US\$1,600) in loans in six years or about PhP11,000 (US\$250) per year, this means that for every PhP100 (US\$2.30) loan taken up, income increased by PhP47 (US\$1.00).

Table 7 further shows that per capita expenditure is also positively affected by access to programme loans. The estimate puts this at about PhP4,136 (US\$95). Using the same calculation employed earlier this would mean PhP38 (US\$0.88) increase in per capita consumption per every PhP100 (US\$2.30) loan taken up.

These estimates of the impact on income and consumption are higher than the well-known estimate of 18 per cent (Pitt and Khandker 1998) and 10 per cent (Khandker 2003). Of course, both used consumption as the dependent variable. Zeller et al. (2001), using data also from Bangladesh, generated similar higher estimates of the impact - an annual average of about 37 per cent - with per capita income as the dependent variable. They used access to credit, rather than loans, as the treatment variable. They

\section{Table 8 Non-GBA loans}

\begin{tabular}{|c|c|c|c|c|c|c|c|}
\hline \multirow[t]{2}{*}{ Variables } & \multicolumn{3}{|c|}{ Existing Areas } & \multicolumn{3}{|c|}{ Expansion Areas } & \multirow[t]{2}{*}{ Total } \\
\hline & $\begin{array}{l}\text { Partici- } \\
\text { pating }\end{array}$ & $\begin{array}{l}\text { Non- } \\
\text { partici- } \\
\text { pating }\end{array}$ & Sig. & $\begin{array}{l}\text { Partici- } \\
\text { pating }\end{array}$ & $\begin{array}{l}\text { Non- } \\
\text { partici- } \\
\text { pating }\end{array}$ & Sig. & \\
\hline Took up non-GBA loans & 0.201 & 0.261 & $* *$ & 0.258 & 0.268 & & 0.248 \\
\hline \multicolumn{8}{|c|}{ Among those with non-GBA loans: } \\
\hline $\begin{array}{l}\text { Amount of other loans, } \\
\text { thousands }\end{array}$ & 20.335 & 17.754 & & 8.776 & 12.357 & & 14.328 \\
\hline Number of other loans & 1.648 & 1.263 & $* * *$ & 1.179 & 1.151 & & 1.280 \\
\hline
\end{tabular}


Table 9 Impact on non-GBA loans

\begin{tabular}{lll}
\hline & $\begin{array}{l}\text { Marginal } \\
\text { effects }\end{array}$ & $\begin{array}{l}\text { Sig. } \\
\text { level }\end{array}$ \\
\hline $\begin{array}{l}\text { Took up non-GBA loans } \\
\text { Amount of non-GBA loans }\end{array}$ & -0.0530 & $\begin{array}{l}0.056 \\
\text { Number of non-GBA loans }\end{array}$ \\
$\begin{array}{ll}\text { Source Operations Evaluation Mission. } \\
\text { ns }\end{array}$ \\
\hline
\end{tabular}

have explained the difference by noting that in using access to credit rather than loans they have captured not only the benefits of loans but also other indirect benefits. These might include the reduced cost of consumption-smoothing (such as decrease in fire sale) and an increase in risk-bearing capacity favouring more profitable production and investment portfolios. Of course, it should be noted that the precision of the estimates is lower in this study.

Savings, in its two definitions, ${ }^{14}$ is not significantly affected. Finally, per capita expenditure on food is also positively affected. The estimate is about PhP1,333 (US\$30) higher compared to those who did not take up programme loans or about PhP12 (US\$28) per every PhP100 (US\$2.30) loan taken up.

Since only the loan availability/access treatment variable was found to be statistically significant on primary measures of welfare, such as per capita income and expenditure, subsequent discussions will be limited to this treatment variable.

\section{Impact on other loans and personal savings}

Besides household income and expenditures, it is also important to look at the impact of the programme on the other financial transactions of the household, such as other loans and maintaining a savings account. The savings referred to here are accounts maintained in the programme MFI and other MFIs and thus can be considered stock rather than the flow savings variable discussed earlier.

About one-fourth of the respondents have taken up non-GBA loans in the last two years (Table 8). About 20 per cent of existing clients have taken up nonGBA loans while a higher proportion (26 per cent) of new clients and non-participating households have taken up non-GBA loans. The amount of non-GBA loans, however, is higher for existing clients (PhP20,000, US\$461) than for new clients (PhP9,000, US\$208) and non-participating households (PhP17,000 and PhP12,000, US\$392 and US\$277 respectively). In terms of the number of loans contracted, the existing clients have a higher number (1.6) compared to new (1.2) and nonparticipating households (1.2).

To determine the impact of the programme on the financial transactions of households, models are estimated with respect to three variables: (a) take-up of non-GBA loans; (b) amount of these other loans; and (c) number of loans transacted. The take-up of non-GBA loan decision was estimated as a binary choice using the probit model. The amount of nonGBA loans decision was estimated as a truncated

Table 10 Saving accounts in the programme and other MFls

\begin{tabular}{|c|c|c|c|c|c|c|c|}
\hline \multirow[t]{2}{*}{ Variables } & \multicolumn{3}{|c|}{ Existing Areas } & \multicolumn{3}{|c|}{ Expansion Areas } & \multirow[t]{2}{*}{ Total } \\
\hline & $\begin{array}{l}\text { Partici- } \\
\text { pating }\end{array}$ & $\begin{array}{l}\text { Non- } \\
\text { partici- } \\
\text { pating }\end{array}$ & Sig. & $\begin{array}{l}\text { Partici- } \\
\text { pating }\end{array}$ & $\begin{array}{l}\text { Non- } \\
\text { partici- } \\
\text { pating }\end{array}$ & Sig. & \\
\hline Have personal savings account & 0.859 & 0.535 & $* * *$ & 0.657 & 0.521 & $* * *$ & 0.637 \\
\hline \multicolumn{8}{|l|}{ Among those with personal savings: } \\
\hline Personal savings $1-5,000$ & 0.653 & 0.652 & & 0.794 & 0.663 & & 0.697 \\
\hline Personal savings $5,000-10,000$ & 0.181 & 0.154 & & 0.128 & 0.139 & & 0.149 \\
\hline Personal savings $10,000+$ & 0.166 & 0.194 & & 0.078 & 0.198 & $* * *$ & 0.154 \\
\hline
\end{tabular}

***, ${ }^{* *},{ }^{*}$ significant at $1 \%, 5 \%$ and $10 \%$ respectively; two-tailed hypothesis

Operations Evaluation Mission. 
Table 11 Impact on savings in the programme and other MFIs

\begin{tabular}{lcc}
\hline & Marginal effects & Sig. level \\
\hline Have personal savings & 0.230 & 0.000 \\
Amount of personal savings & & \\
$0-5,000$ & -0.124 & 0.003 \\
$5-10,000$ & 0.038 & 0.001 \\
10,000 & 0.086 & 0.005 \\
Source Operations Evaluation Mission. & & \\
\hline
\end{tabular}

variable using the tobit model. Finally, the number of non-GBA loans transacted was estimated as a count variable using Poisson regression. All of these are non-linear models. Thus, as mentioned in 3.3, the control function uses the propensity score method. The results show that the treatment variable - takeup of programme loan - is significant in the take-up of non-GBA loan variable and insignificant in the amount and number of non-GBA loans contracted.

Table 9 provides the summary of the estimates of the impact on non-GBA loans. The estimates show that availability of programme loans significantly, albeit marginally (significance 6 per cent), reduced the use of non-GBA loans. The estimated coefficient shows that compared to non-programme respondents the non-GBA loans contracted in the last two years was reduced by about 5 per cent. ${ }^{15}$ As mentioned earlier, in terms of loan amount and the number of non-GBA loans contracted, however, the impact is statistically insignificant.

In terms of personal savings ${ }^{16}$ (stocks), about twothirds of the respondents maintain personal savings accounts either in the programme or nonprogramme MFls (3.10). This is higher for existing clients (86 per cent) than for new clients (66 per cent) and non-participating ( 54 per cent and 52 per cent) households. In terms of balances, about 70 per cent of households have PhP1-5,000 (US\$115), 15 per cent have PhP5,000-10,000 (US\$230) and the remaining 15 per cent more than PhP10,000.

To determine the impact of the programme on personal savings, models of the decision to maintain a savings account and the balances of those accounts were developed. The decision to maintain a savings account is estimated as a probit model while the

Table 12 Household enterprises and employment

\begin{tabular}{|c|c|c|c|c|c|c|c|}
\hline \multirow[t]{2}{*}{ Variables } & \multicolumn{3}{|c|}{ Existing Areas } & \multicolumn{3}{|c|}{ Expansion Areas } & \multirow[t]{2}{*}{ Total } \\
\hline & $\begin{array}{l}\text { Partici- } \\
\text { pating }\end{array}$ & $\begin{array}{l}\text { Non- } \\
\text { partici- } \\
\text { pating }\end{array}$ & Sig. & $\begin{array}{l}\text { Partici- } \\
\text { pating }\end{array}$ & $\begin{array}{l}\text { Non- } \\
\text { partici- } \\
\text { pating }\end{array}$ & Sig. & \\
\hline $\begin{array}{l}\text { With household enterprise } \\
\text { Among those with } \\
\text { household enterprise: }\end{array}$ & 0.926 & 0.777 & $* * *$ & 0.871 & 0.779 & $* * *$ & 0.836 \\
\hline Total no of enterprises & 2.07 & 1.63 & $* * *$ & 1.82 & 1.63 & $* * *$ & 1.79 \\
\hline $\begin{array}{l}\text { Employed family members } \\
\text { Employed non-family }\end{array}$ & 2.31 & 1.62 & $* * *$ & 1.68 & 1.66 & & 1.82 \\
\hline members & 0.63 & 0.78 & & 0.68 & 0.33 & & 0.61 \\
\hline Total employed & 2.95 & 2.40 & $* *$ & 2.36 & 2.00 & & 2.43 \\
\hline
\end{tabular}


Table 13 Impact on enterprises and employment

\begin{tabular}{lll}
\hline & Incidence rate & Sig. Level \\
\hline Total no of enterprises & 1.20 & 0.009 \\
Total no of employees & 1.17 & 0.006 \\
& \\
Source Operations Evaluation Mission.
\end{tabular}

modelling for the savings balances uses an ordered probit model considering the three ordered categories of savings balances mentioned earlier. Again these are non-linear models so the propensity score method was used for the control function. The results show that both maintaining personal savings accounts and the amount of balances are significantly affected by taking up programme loans.

Table 11 shows the summary of the estimation results indicating that the impact of the programme is positive and highly statistically significant (significance less than 1 per cent) in terms of both having a personal savings account and on the amount of savings. The estimates show that, of those who have maintained savings accounts, clients who have taken up programme loans exceed non-programme clients by as much as 23 per cent. In terms of the amount of savings, the proportion of programme clients with $\mathrm{PhPO}-5,000$ is lower by 12 per cent, those with PhP5-10,000 higher by 4 per cent and those with more than $\mathrm{PhP10}, 000$ higher by 9 per cent than those who did not take up programme loans.

Impact on the number of enterprises and employment Another important impact of microfinance is what it does to the enterprises the respondent households are engaged in. The survey asked respondents about the enterprises and employment in these enterprises of programme clients as well as other household members.

Table 12 shows that about 93 per cent of the existing client respondents have household enterprises. This is higher compared to new clients (87 per cent) and non-participating households (78 per cent). Among those with household enterprises, the number of enterprises per household is about 1.8 and the total number of employed people is about 2.4. For existing clients, this is about 2.1 enterprises employing about 3 individuals. For new clients, this is about 1.8 enterprises employing 2.4 individuals. For non-participating households in treatment and expansion areas, this is 1.6 enterprises employing 2.4 and 2.0 individuals, respectively.

Since substitutions can happen between programme clients' enterprises and those of other household members, the analysis is focused only on total enterprise and total employment. The modelling of the number of enterprises and number of employees considered these variables as counts which were estimated using Poisson regression. Since this is a non-linear model, the propensity score method was used for the control function. The estimation results show that the take-up of programme loans significantly affected the number of enterprises households have as well as the number of employees in these enterprises.

The estimates show that the impact of the programme on both the number of enterprises as well as the number of employed persons in these enterprises is a very significant positive. Table 13 shows that compared to non-programme households, the number of enterprise households with programme clients is higher by 20 per cent.17 The table also shows that households with programme clients have 17 per cent more employed persons than non-programme clients.

\section{Impact on assets}

It is very likely that microfinance will affect household acquisition of assets. The respondent households were asked about the current value of their assets. The standard question asked about assets is 'if someone wanted to buy a particular owned asset, what would the price be?'. The assets include land, equipment, livestock and poultry, and household amenities.

Table 14 shows that about 20 per cent of the respondents have land assets with an average current value of PhP557,000 (US\$12,850). It also shows about 15 per cent of the respondents own farm equipment with an average current value of PhP55,000 (US\$1270). About 53 per cent of the respondents have livestock and poultry assets with an average current value of PhP46,000 (US\$1,060). Finally, almost all (97 per cent) have some household appliances with a current value of PhP73,000 (US\$1,680).

The value of total assets per household was estimated as a truncated variable (having only positive 
Table 14 Household assets

\begin{tabular}{|c|c|c|c|c|c|c|c|}
\hline \multirow[t]{2}{*}{ Variables } & \multicolumn{3}{|c|}{ Existing Areas } & \multicolumn{3}{|c|}{ Expansion Areas } & \multirow[t]{2}{*}{ Total } \\
\hline & $\begin{array}{l}\text { Partici- } \\
\text { pating }\end{array}$ & $\begin{array}{l}\text { Non- } \\
\text { partici- } \\
\text { pating }\end{array}$ & Sig. & $\begin{array}{l}\text { Partici- } \\
\text { pating }\end{array}$ & $\begin{array}{l}\text { Non- } \\
\text { partici- } \\
\text { pating }\end{array}$ & Sig. & \\
\hline With agriculture and comm. land & 0.198 & 0.179 & & 0.231 & 0.231 & 0.190 & 0.199 \\
\hline $\begin{array}{l}\text { Among those with ag. and comm. land: } \\
\text { Agri. and commercial land, curr. value } \\
\text { With farm equipment }\end{array}$ & $\begin{array}{l}468,338 \\
0.117\end{array}$ & $\begin{array}{l}581,081 \\
0.124\end{array}$ & & $\begin{array}{l}580,559 \\
0.194\end{array}$ & $\begin{array}{l}590,688 \\
0.167\end{array}$ & & $\begin{array}{l}557,332 \\
0.151\end{array}$ \\
\hline $\begin{array}{l}\text { Among those with farm equipment: } \\
\text { Farm equipment, curr. value } \\
\text { With livestock and poultry }\end{array}$ & $\begin{array}{l}27,588 \\
0.586\end{array}$ & $\begin{array}{l}34,108 \\
0.490\end{array}$ & $* * *$ & $\begin{array}{l}110,645 \\
0.565\end{array}$ & $\begin{array}{l}24,885 \\
0.472\end{array}$ & $* * *$ & $\begin{array}{l}55,365 \\
0.527\end{array}$ \\
\hline $\begin{array}{l}\text { Among those with livestock and poult: } \\
\text { Livestock and poultry, curr. value } \\
\text { With household appliances }\end{array}$ & $\begin{array}{l}20,419 \\
0.981\end{array}$ & $\begin{array}{l}18,556 \\
0.973\end{array}$ & & $\begin{array}{l}83,484 \\
0.968\end{array}$ & $\begin{array}{l}58,183 \\
0.958\end{array}$ & & $\begin{array}{l}46,028 \\
0.970\end{array}$ \\
\hline $\begin{array}{l}\text { Among those with household appliances: } \\
\text { Household appliances, curr. value }\end{array}$ & 59,547 & 66,689 & & 121,606 & 44,252 & & 73,311 \\
\hline
\end{tabular}

\begin{tabular}{|c|c|c|c|c|c|c|c|}
\hline \multirow[t]{2}{*}{ Variables } & \multicolumn{2}{|c|}{ Existing Areas } & \multirow[b]{2}{*}{ Sig. } & \multicolumn{3}{|c|}{ Expansion Areas } & \multirow[t]{2}{*}{ Total } \\
\hline & $\begin{array}{l}\text { Partici- } \\
\text { pating }\end{array}$ & $\begin{array}{l}\text { Non- } \\
\text { partici- } \\
\text { pating }\end{array}$ & & $\begin{array}{l}\text { Partici- } \\
\text { pating }\end{array}$ & $\begin{array}{l}\text { Non- } \\
\text { partici- } \\
\text { pating }\end{array}$ & Sig. & \\
\hline With children 6-12 years old & 0.502 & 0.499 & & 0.576 & 0.472 & $* * *$ & 0.512 \\
\hline $\begin{array}{l}\text { Among those with children 6-12: } \\
\text { Proportion attending school, 6-12 } \\
\text { With children } 13-16 \text { years old }\end{array}$ & $\begin{array}{l}0.970 \\
0.416\end{array}$ & $\begin{array}{l}0.959 \\
0.345\end{array}$ & ** & $\begin{array}{l}0.944 \\
0.393\end{array}$ & $\begin{array}{l}0.927 \\
0.326\end{array}$ & $* *$ & $\begin{array}{l}0.950 \\
0.369\end{array}$ \\
\hline $\begin{array}{l}\text { Among those with children 13-16: } \\
\text { Proportion attending school, 13-16 } \\
\text { With children 17-24 years old }\end{array}$ & $\begin{array}{l}0.881 \\
0.490\end{array}$ & $\begin{array}{l}0.915 \\
0.372\end{array}$ & $* * *$ & $\begin{array}{l}0.869 \\
0.426\end{array}$ & $\begin{array}{l}0.817 \\
0.439\end{array}$ & & $\begin{array}{l}0.871 \\
0.430\end{array}$ \\
\hline $\begin{array}{l}\text { Among those with children 17-24: } \\
\text { Educ. exp. per school age child } \\
\text { Educ. exp. per attending child }\end{array}$ & $\begin{array}{l}0.344 \\
5,931 \\
8,241\end{array}$ & $\begin{array}{l}0.319 \\
6,301 \\
8,313\end{array}$ & & $\begin{array}{l}0.306 \\
4,615 \\
6,300\end{array}$ & $\begin{array}{l}0.278 \\
4,525 \\
6,128\end{array}$ & & $\begin{array}{l}0.312 \\
5,312 \\
7,239\end{array}$ \\
\hline
\end{tabular}


Table 16 Health outcomes

\begin{tabular}{|c|c|c|c|c|c|c|c|}
\hline \multirow[t]{2}{*}{ Variables } & \multicolumn{3}{|c|}{ Existing Areas } & \multicolumn{3}{|c|}{ Expansion Areas } & \multirow[t]{2}{*}{ Total } \\
\hline & $\begin{array}{l}\text { Partici- } \\
\text { pating }\end{array}$ & $\begin{array}{l}\text { Non- } \\
\text { partici- } \\
\text { pating }\end{array}$ & Sig. & $\begin{array}{l}\text { Partici- } \\
\text { pating }\end{array}$ & $\begin{array}{l}\text { Non- } \\
\text { partici- } \\
\text { pating }\end{array}$ & Sig. & \\
\hline $\begin{array}{l}\text { Proportion of members ill/injured } \\
\text { With illness/injured members }\end{array}$ & $\begin{array}{l}0.097 \\
0.255\end{array}$ & $\begin{array}{l}0.072 \\
0.181\end{array}$ & $* * *$ & $\begin{array}{l}0.101 \\
0.269\end{array}$ & $\begin{array}{l}0.091 \\
0.213\end{array}$ & $* *$ & $\begin{array}{l}0.090 \\
0.229\end{array}$ \\
\hline $\begin{array}{l}\text { Among those ill/injured members: } \\
\text { Proportion who seek treatment } \\
\text { With children } 0-5 \text { years old }\end{array}$ & $\begin{array}{l}0.700 \\
0.323\end{array}$ & $\begin{array}{l}0.685 \\
0.430\end{array}$ & $* * *$ & $\begin{array}{l}0.696 \\
0.444\end{array}$ & $\begin{array}{l}0.657 \\
0.394\end{array}$ & & $\begin{array}{l}0.686 \\
0.399\end{array}$ \\
\hline $\begin{array}{l}\text { Among those with children } 0-5 \text { years } \\
\text { Proportion fully immunised } \\
\text { Per capita medical exp. }\end{array}$ & $\begin{array}{l}\text { old: } \\
0.717 \\
645\end{array}$ & $\begin{array}{l}0.666 \\
954\end{array}$ & & $\begin{array}{l}0.719 \\
560\end{array}$ & $\begin{array}{l}0.659 \\
791\end{array}$ & & $\begin{array}{l}0.689 \\
740\end{array}$ \\
\hline
\end{tabular}

values) using a tobit model. In fact, as Table 14 shows, a substantial proportion of households do not have specific assets. Since this is a non-linear model, the propensity score method was used for the control function. The estimations did not show significant impact of the programme on total household assets.

\section{Impact on human capital investments (education and health)}

Any change in income or expenditure does not necessarily translate into changes in human capital investments. The education variables examined are school attendance of school-age children (6-12 years, 13-16 years, and $17-24$ years) as well as the education expenditure per school-attending child. For health, the variables examined are the proportion of household members who are ill or injured, the proportion of those ill or injured who sought medical treatment, the proportion of children 0-5 years who are fully immunised, and per capita health expenditures.

Table 15 shows that about 95 per cent of children 6-12 years old, 87 per cent of children $13-16$ years, and 31 per cent of children 17-24 years old are attending school. It also shows that the average expenditure per attending school-age child is about PhP7,239 (US\$167). In terms of health indicators, Table 16 shows that the proportion of either sick or injured in the 6 months preceding the survey is about 9 per cent. The proportion of households with at least one ill/injured member is about 23 per cent. The proportion of those ill/injured who sought treatment is 69 per cent. The proportion of children 0-5 years old who are fully immunised is about 69 per cent. The average per capita expenditure for health is about PhP740 (US\$17).

Table 17 Hunger and reduced food consumption incidence

\begin{tabular}{|c|c|c|c|c|c|c|c|}
\hline \multirow[t]{2}{*}{ Variables } & \multicolumn{3}{|c|}{ Existing Areas } & \multicolumn{3}{|c|}{ Expansion Areas } & \multirow[t]{2}{*}{ Total } \\
\hline & $\begin{array}{l}\text { Partici- } \\
\text { pating }\end{array}$ & $\begin{array}{l}\text { Non- } \\
\text { partici- } \\
\text { pating }\end{array}$ & Sig. & $\begin{array}{l}\text { Partici- } \\
\text { pating }\end{array}$ & $\begin{array}{l}\text { Non- } \\
\text { partici- } \\
\text { pating }\end{array}$ & Sig. & \\
\hline Hunger incidence & 0.023 & 0.032 & & 0.019 & 0.014 & & 0.017 \\
\hline Reduced food incidence & 0.113 & 0.124 & & 0.110 & 0.105 & & 0.107 \\
\hline
\end{tabular}


Table 18 Impact on household outcome by per capita income

\begin{tabular}{lccccccccccc}
\hline & \multicolumn{2}{c}{ Per Capita Income } & \multicolumn{2}{c}{$\begin{array}{c}\text { Per Capita } \\
\text { Expenditure }\end{array}$} & $\begin{array}{c}\text { Per Capita } \\
\text { Savings } 1\end{array}$ & $\begin{array}{c}\text { Per Capita } \\
\text { Savings } 2\end{array}$ & $\begin{array}{c}\text { Per Capita Food } \\
\text { Expenditures }\end{array}$ \\
\hline Coeff. Sig. Lev. & Coeff. Sig. Lev. & Coeff. Sig. Lev. & Coeff. Sig. Lev. & Coeff. & Sig. Lev. \\
\hline Quartile 1 & $-23,214.0$ & 0.000 & $-9,459.7$ & 0.007 & $-13,754.2$ & 0.000 & $-14,567.2$ & 0.000 & $-3,476.9$ & 0.002 \\
Quartile 2 & $-13,903.1$ & 0.001 & $-6,752.6$ & 0.034 & $-7,150.6$ & 0.006 & $-7,680.6$ & 0.005 & $-1,508.5$ & 0.164 \\
Quartile 4 & $-1,212.2$ & -0.764 & $1,849.6$ & 0.548 & $-3,061.8$ & 0.228 & -3010.6 & 0.251 & $1,382.1$ & 0.159 \\
\hline
\end{tabular}

Coeff. $=$ Coefficients, Sig. Lev. $=$ Significance Level

Source Operations Evaluation Mission.

Two types of variable were considered in modelling the impact of the programme on education variables, namely: (a) proportion of school-age children attending school and (b) expenditure per attending child. The proportion of school-age children attending school was used in order to be closer to the notion of a household decision variable. ${ }^{18}$ With a proportion as a dependent variable, the fractional logit mode ${ }^{19}$ was used to estimate it. In the case of expenditure per attending child this was estimated using a linear fixed-effects model because this is a continuous variable. In terms of the control function, the fractional logit model, being a non-linear model, used propensity scoring while the expenditure per attending child used the interaction between the treatment variable and the demeaned values of the other independent variables. The estimation results show that take-up of a programme loan is not significant for school attendance for any age group nor for expenditure per attending child.
In the case of health, four variables were used, namely: (a) proportion ill or injured, (b) proportion who seek treatment if ill or injured, (c) proportion of fully immunised children $0-5$ years old, and (d) per capita medical expenditures. Similar to the treatment of the school attendance variables, variables (a) to (c) were modelled as proportions using a fractional logit model. Per capita medical expenditures, on the other hand, were modelled as a continuous variable using linear fixed-effects. The results show that take-up of a programme loan does not significantly affect all health variables under consideration.

Impact on hunger incidence and reduction in food consumption

Hunger incidence as well the reduction in food consumption in the last three months was likewise studied. Table 17 shows that hunger incidence is about 2 per cent in the respondent population. Reduction in food consumption over the last three

Table 19 Distribution of average loan size by per capita income quartile

\begin{tabular}{|c|c|c|c|}
\hline Quartile & $\begin{array}{l}\text { Mean cumulative loans } \\
\text { (P'000) }\end{array}$ & Total number of cycles & Average loan size (P’000) \\
\hline Lowest & 45,031 & 6.1 & 7,392 \\
\hline Lower middle & 57,540 & 6.9 & 8,280 \\
\hline Upper middle & 64,290 & 7.1 & 9,087 \\
\hline Highest & 99,168 & 8.2 & 12,166 \\
\hline Total & 69,923 & 7.2 & 9,721 \\
\hline
\end{tabular}


Table 20 Distribution of type of client by per capita income quartile (\%)

\begin{tabular}{lcccccc}
\hline Quartile & Existing & Graduates & Problem & New & Non-Participating & Total \\
\hline Lowest & 14.96 & 0.55 & 2.37 & 27.01 & 55.11 & 100 \\
Lower Middle & 18.43 & 0.54 & 2.68 & 26.30 & 52.06 & 100 \\
Upper Middle & 21.34 & 0.54 & 2.17 & 27.49 & 48.46 & 100 \\
Highest & 27.50 & 0.36 & 0.89 & 21.61 & 49.64 & 100 \\
Total & $\mathbf{2 0 . 5 9}$ & $\mathbf{0 . 5 0}$ & $\mathbf{2 . 0 3}$ & $\mathbf{2 5 . 5 9}$ & $\mathbf{5 1 . 3 1}$ & $\mathbf{1 0 0}$
\end{tabular}

Operations Evaluation Mission.

months, on the other hand, is found in 11 per cent of the respondent households.

Hunger incidence was modelled as a binary outcome using the probit model. Since this a non-linear model, the propensity score method was used for the control variables. The estimation results show that take-up of a programme loan did not significantly affect the incidence of hunger.

\section{Impact by different socioeconomic groups}

The evaluation of the programme was also designed to test whether the impact of access to microcredit differed across socioeconomic groups. While the poor/non-poor distinction is useful, a better picture is given by dividing the sample households into per capita income quartiles. There are a couple of ways of estimating the impact on different subgroups. One is estimating a separate equation for each subgroup. Another is to jointly estimate the impact in a single equation using the interaction of subgroup and treatment variables, i.e., using the coefficient of the interaction between the availability treatment variable and corresponding quartile dummy variables to measure the impact for each quartile. Orr (1997) argues that the latter approach has two advantages: (1) it usually provides more power because it uses the full sample to estimate the coefficients; and (2) it allows one to test whether there are statistically significant differences in impact among the subgroups taken as a set (rather than between pairs of subgroups). Given these considerations, the joint estimation method was adopted for this study. The survey respondents were divided into four quartiles, i.e., those (1) with annual per capita incomes less than PhP21,480 (US\$496); (2) PhP21,481-34,428 (US\$794); (3) PhP34,429-56,167 (US\$1,296); and (4) over PhP56,167. For comparative purposes, it is useful to mention that the poverty line in the Philippines is equivalent to an annual per capita income of PhP14,405 (US\$332) and for rural households this is PhP13,659 (US\$315). ${ }^{20}$

The results show that the programme had a regressive impact. $A$ significant positive impact was evident only for the households in the top quartile while there was a negative impact on the poorer households. For instance, per capita income for the participating households in the poorest quartile was PhP23,000 (US\$530) lower than for the nonparticipating households. However, the impact for the top quartile was positive and resulted in a PhP45,000 (US\$1,040) increase in annual income compared with the non-participating households in the same income group. The results were similar for per capita expenditure, savings, and food expenditure. It is worth noting that the impact on savings is significant for all except the third quartile in contrast to the insignificant impact for the whole sample.

There are several possible reasons why the impact on the lower-income households is lower (or negative). These include: (1) the problem clients are concentrated among the poorer households; (2) the average size of loans may be smaller for poorer households; (3) there may be a tendency among poorer households to divert loan proceeds from production to consumption; and (4) if there is no diversion, the projects of poorer households may be less productive. In this study, there is empirical evidence only for (1) and (2).

Indeed, the average loan size for poorer households is smaller (Table 19). This prevents them for venturing into more productive activities that would require more capital. Table 20 shows that there are more 
Table 21 Impact on household outcome by education status of reference person

\begin{tabular}{|c|c|c|c|c|c|c|c|c|c|c|}
\hline \multirow{3}{*}{$\begin{array}{l}\begin{array}{l}\text { Education } \\
\text { status }\end{array} \\
\\
\text { At most } \\
\text { elementary } \\
\text { grade }\end{array}$} & \multicolumn{2}{|c|}{$\begin{array}{l}\text { Per Capita } \\
\text { Income }\end{array}$} & \multirow{2}{*}{\multicolumn{2}{|c|}{$\begin{array}{c}\text { Per Capita } \\
\text { Expenditure }\end{array}$}} & \multirow{2}{*}{\multicolumn{2}{|c|}{$\begin{array}{c}\text { Per Capita } \\
\text { Savings } 1\end{array}$}} & \multirow{2}{*}{\multicolumn{2}{|c|}{$\begin{array}{c}\text { Per Capita } \\
\text { Savings } 2\end{array}$}} & \multicolumn{2}{|c|}{$\begin{array}{l}\text { Per Capita Food } \\
\text { Expenditures }\end{array}$} \\
\hline & \multirow{2}{*}{$\begin{array}{l}\text { Coeff. } \\
-5,864\end{array}$} & \multirow{2}{*}{$\begin{array}{c}\text { Sig. Lev. } \\
0.154\end{array}$} & & & & & & & Coeff. & Sig. Lev. \\
\hline & & & $-1,511$ & 0.619 & $-4,353$ & 0.083 & $-4,904$ & 0.060 & -45 & 0.962 \\
\hline Secondary & 9,727 & 0.009 & 7,302 & 0.009 & 2,425 & 0.288 & 3,521 & 0.138 & 1,567 & 0.074 \\
\hline $\begin{array}{l}\text { At least } \\
\text { some tertiary }\end{array}$ & $y^{9,805}$ & 0.034 & 4,206 & 0.218 & 5,600 & 0.047 & 6,353 & 0.030 & 2,254 & 0.037 \\
\hline
\end{tabular}

Coeff. $=$ Coefficients, Sig. Lev. = Significance Level

Source Operations Evaluation Mission.

problem clients among the bottom three quartiles. While the average proportion of problems in the sample is about 2 per cent, the bottom three quartiles each have a little over 2 per cent problem clients while the highest per capita income quartile group only had less than 1 per cent problem clients.

The regressive relationship provides further evidence that microfinance projects should not target the ultra poor. Additional debt may make their lives worse, not better. Coleman (2006), using data from Thailand, qualified the earlier 'no significant impact on consumption' result in Coleman (1999) with a positive impact for the centre leaders, who are also the more well-off segment of the membership. The insignificant impact on poorer members was confirmed. On the other hand, Hulme and Mosley (1996) - using data from Indonesia, India, Bangladesh, and Sri Lanka - found a positive impact on income on average but, like Coleman (2006), also found a larger impact for the better-off members. Thus, the regressive result of this study is consistent with some of the findings reported in the literature. This indicates that among poorer borrowers, the availability of microcredit loans is not sufficient to ensure that the ultra poor invest in sufficiently productive activities to generate the income necessary to repay the loans and earn some profit.

It can be argued that the use in the preceding analyses of income quartiles to determine the impact across socioeconomic grouping may be problematic because income is affected by the treatment variable. ${ }^{21}$ To avoid the endogeneity problem, we reestimated the above equations using the education attainment of the reference person - which is known to be directly related to socioeconomic status and is presumably acquired prior to the programme. The summary of estimation results is given in Table 21. The results substantially replicated the regressive impact. While the table shows that, for those with elementary education at most, the impact on per capita income is negative, this is not statistically significant. But the impacts for those with secondary and elementary education are significantly positive and rising with higher educational attainment.

\section{Summary, conclusion and recommendations}

The study used a quasi-experimental design (from Coleman 1999) to control for non-random programme participation and fixed-effects estimation to correct for non-random programme placement. In addition, it included former clients to correct for non-random attrition/dropout problems which were not considered in the original Coleman (1999) design. It also used recommended estimation procedures for estimating average treatment effects described in Wooldridge (2002)

The survey results indicate that a majority of the existing clients, new clients, and non-participating households deemed qualified for the programme are not poor according to the official definition. This is in sharp contrast to the other studies which indicated that the majority of microfinance programme clients are poor. Khandker (2003), for instance, indicates that 
90 per cent of the microfinance programme participants in Bangladesh in the 1991/92 survey and 70 per cent in the 1998/99 survey are poor. Montgomery (2005) found that 70 per cent of microfinance clients of the Khushhali Bank in Pakistan are poor. Given these findings there is a need to reexamine the targeting approach of the microfinance implementers in the Philippines. It could be that the targeting approaches have the potential to identify the desired clients but that these are just not implemented strictly enough. Another factor that needs to be looked at is whether there is enough motivation for the implementers to seek out poor clients. These have important implications for the design of microfinance programmes.

The impact of the availability of programme loans on per capita income is shown to be positive and marginally significant. This is also true for per capita total expenditure and per capita food expenditure. But it was also found that this impact is regressive, that it is negative or insignificant for poorer households and becomes only positive and increasing with richer households. This negative or insignificant impact for poorer households and positive impact for richer households provides some explanation for the slight significance of the coefficient for the total sample. It is worth mentioning that this is not the only study that found a regressive impact. Coleman (2006), using data from Thailand, qualified the earlier 'no significant impact on consumption' result in Coleman (1999) with the finding of a positive impact for the centre leaders (the richer segment of the membership) and the finding that the insignificant impact is confined to poorer members. Hulme and Mosley (1996) using data from Indonesia, India, Bangladesh and Sri Lanka, on the other hand, found positive impact on income on average but, in addition, like Coleman (2006) also found larger impact for better-off members. Thus the regressive result of this study may not be entirely surprising but is certainly disturbing. This indicates that among poorer borrowers the cost of and availability of programme loans appears to be insufficient to stimulate them to select more productive activities that will not only cover the cost of borrowing but also earn them some profit. One can also view this as the result of MFls not screening projects carefully enough to produce the desired results. This implies that attention to project selection must also be an important component of programme design.
The programme has enabled participants to reduce dependence on presumably higher-priced non-GBA loans. In addition, it has increased the proportion of those having savings accounts in the programme and other MFIs. It has also increased the amounts saved in those accounts. Together these imply better consumption-smoothing capabilities.

Another significant impact of the programme is making programme clients busier and engaged in a larger number of enterprises. This likewise resulted in greater numbers of employed workers in these enterprises. Given the thrust of the programme to cater to micro-entrepreneurs, this result is hardly surprising.

Finally, the study also found no significant impact on household assets or on human capital investments such as health and education. It appears that the slight impact on income and expenditures was not sufficient to drastically change either accumulation of household assets or human capital investments.

In summary, the microfinance programme has kept programme clients economically active with more enterprises and more employees. It has also improved consumption-smoothing capabilities with lesser dependence on presumably higher-priced nonGBA loans and has increased savings in both programme and non-programme MFls. Nonetheless, the impact on per capita income, total expenditures, and food expenditures is only slightly significant but with regressive features.

Considering the above, for microfinance to be an effective poverty-alleviation tool there is a need to review targeting procedures to know whether these are correctly identifying the intended beneficiaries. There is also a need to regularly assess the economic status of clients to avoid drifting away from the focus on poor and low-income households. This cannot be emphasised enough, considering that MFls may not have sufficient motivation to seek out poor clients. Finally, considering the regressive impact on income, there is a need to assist the poor in improving the selection of projects so that these do not only ensure repayment of the loans but also generate ample profit. Again, in project selection the concern of the MFIs may be limited to just ensuring repayment and not generating profits for their clients. 


\section{Notes}

* Toshio Kondo, Team Leader and Senior Evaluation Specialist, Asian Development Bank; Aniceto C. Orbeta, Jr., Econometrician/Impact Evaluation Specialist/Consultant of the Project; Clarence Dingcong, Microfinance Specialist/Consultant of the Project; and Christine Infantado, Portfolio Evaluation Officer, Asian Development Bank. Bihn Nguyen of the Economics and Research Department, Asian Development Bank, provided assistance at the initial stage of the study. This report also benefited from the comments of David Levine, Professor, University of California, Berkeley. The full report is available at www.adb.org/Documents/SES/REG/SST-REG2007-19/SST-REG-2007-19.asp

1 A barangay is a village, and is the smallest political unit in the Philippines.

2 The identified factors are adopted from Armendariz de Aghion and Morduch (2005).

3 This has also been rendered as $Y_{i j}=F\left(\beta_{1} \cdot X_{i j}+\beta_{2} \cdot V_{j}\right.$ $\left.+\beta_{3} M_{i j}+\beta_{4}{ }^{*} M_{i j} T_{i j}+\varepsilon_{i j}\right)$ where $T_{i j}=$ treatment variable; 1 (or $>0$ ) for treatment areas (cf. Armendariz de Aghion and Morduch, 2005).

4 The MFls did not keep a record of eligible households in the communities where they are operating. Thus there is no way of knowing whether the list of non-participating households is comprehensive or not without going into a listing operation. Household listing, however, was not done due to resource limitations. This should be considered as a limitation of the study.

5 This refers to savings (stocks) accounts held by the respondent in the programme MFI or other MFIs and is different from the savings (flow) variables measured as the difference in income and expenditures.

6 Originally attributed to Rosenbaum and Rubin (1983), this concept is defined as conditional on observable characteristics; the treatment and outcome variables are independent. Practically, it means that the treatment variable must not be under the control of the respondent.

7 Coleman (1999) prefers to use the highest educational attainment achieved by any member in the household.

8 The ideal wealth variable would be household assets pre-dating the availability of the programme. This was not available from the data set because of recall problems. Coleman (1999), for instance, used the value of assets acquired five years ago.
9 Barangay variables could have been used, but the study experienced significant refusals for the Barangay Profile Survey (BPS) which would significantly reduce the number of observations if used. Eleven barangays did not accomplish the BPS which would mean removal of about 220 household respondents if the barangay profile data were used.

10 Other candidate variables would be barangay characteristics. However, as mentioned earlier, the study experienced a significant refusal problem with this instrument. We are grateful to $D$. Levine for pointing out that using treatment variable (2) as the instrument for treatment variables (3) and (4) will not be very different from using treatment variable (2) directly. Since these treatment variables did not turn out to be significant in the estimation results they were not used in subsequent discussions.

11 The reference person is the person in the household to whom all relationships with other household members are referenced. This person is commonly known as the household head.

12 This is published in the National Statistics Coordination Board website (www.nscb.gov.ph). The national poverty threshold for rural areas is estimated to be PhP13,659 while the food threshold is PhP9,445 as of 7 March 2006.

13 Defined as those below the food threshold.

14 One definition is income minus expenditures. The second definition adds back expenditures on education, health, and durable furniture because these are not expected to be consumed in one period (see for instance Bautista and Lamberte 1990).

15 This is estimated as a non-linear probit model so the marginal effects on the probability of contracting a non-GBA loan are presented

16 The respondents were asked about their savings accounts both in the programme MFI and in other MFIs.

17 Since this is a Poisson regression, incidence rate (exp(coefficient)) is given. This is given in the column labeled as IRR.

18 This can also be estimated as an individual-based decision model, i.e. attendance of each schoolage child is treated independently. This, however, may not capture the idea that the attendance of all school-age children in the household is jointly decided on by parents.

19 Adopting the method used in Papke and Wooldridge (1996). 
20 Estimates as of 7 March 2006 from the National Statistics Coordination Board website. Available: www.nscb.gov.ph.

\section{References}

Amin, S.; Rai, A.S. and Ropa, G. (2003) 'Does Microcredit Reach the Poor and Vulnerable? Evidence from Northern Bangladesh', Journal of Development Economics 70.1: 59-82

Armendariz de Aghion, B. and Morduch, J. (2005) The Economics of Microfinance, Cambridge, MA: MIT Press

Bautista, R. and Lamberte, M. (1990) 'Comparative Savings Behavior of Rural and Urban Households in the Philippines', Journal of Philippine Development 27.2: 149-81

Coleman, B. (2006) 'Microfinance in Northeast Thailand: Who Benefits and How Much?', World Development 34.9: 1612-38

Coleman, B. (1999) 'The Impact of Group Lending in Northeast Thailand', Journal of Development Economics 60: 105-41

Hulme, D. and Mosley, P. (1996) Finance Against Poverty, Vol 1 and 2, London: Routledge

Karlan, D. (2001) 'Microfinance Impact Assessments: The Perils of Using New Members as Control Group', Journal of Microfinance, December

Khandker, S. (2003) Micro-Finance and Poverty: Evidence Using Panel Data from Bangladesh, WB Policy Research Working Paper 2945, Washington DC: World Bank

Khandker, S. (1998) Fighting Poverty with Microcredit: Experience from Bangladesh, New York: Oxford University Press
21 We are grateful to D. Levine for pointing this out.

Montgomery, H. (2005) Serving the Poorest of the Poor: The Poverty Impact of the Khushhali Bank's Microfinance Lending in Pakistan, Manila: ADB Institute

Orr, L. (1997) Social Experimentation: Evaluating Public Programs with Experimental Methods, Washington DC: Department of Human Services

Papke, L. and Wooldridge, J. (1996) 'Econometric Methods for Fractional Response Variables with an Application to 401(k) Plan Participation Rates', Journal of Applied Econometrics 11: 619-32

Pitt, M. and Khandker, S. (1998) 'The Impact of Group-Based Credit Programs on Poor Households in Bangladesh: Does the Gender of Participants Matter?', Journal of Political Economy 106.2: 958-96

Rosenbaum, P. and Rubin, D. (1983) 'The Central Role of Propensity Score in Observational Studies for Causal Effects', Biometrika 70: 41-55

Wooldridge, J (2002) Econometric Analysis of Cross Section and Panel Data, Cambridge, MA: MIT Press

Zeller, M.; Sharma, M.; Ahmed, A. and Rashid, S. (2001) Group-Based Financial Institutions for the Rural Poor in Bangladesh: An Institutional- and Household-Level Analysis, International Food Policy Research Institute (IFPRI) 